\title{
Adult Mortality and Consumption Growth in the Age of HIV/AIDS
}

\author{
KATHLEEN BEEGLE \\ World Bank \\ JOACHIM DE WEERDT \\ EDI, Tanzania \\ STEFAN DERCON \\ Oxford University
}

\section{Introduction}

While there are other more prevalent diseases in Africa, the characteristics of HIV/AIDS suggest that its economic and demographic impact will be profound. In the absence of the AIDS epidemic, prime-age deaths would be relatively rare in Africa. Because $\mathrm{HIV}$ in Africa is transmitted primarily through heterosexual contact, the epidemic is having a dramatic impact on the mortality of men and women in their prime childbearing and earning years; consequently, the mortality rates of adults aged 15-50 increase dramatically in areas affected by the epidemic (Ngom and Clark 2003). Moreover, $\mathrm{HIV} / \mathrm{AIDS}$ is not restricted to poorer populations. Unlike other major diseases in Africa, HIV/AIDS is prevalent among the better-educated and higherincome Africans in urban areas, while there is mixed evidence about the correlation between socioeconomic status and HIV. For example, earlier evidence (World Bank 1999) indicated higher rates among better-educated/higher income groups, whereas more recent population survey data analyzed by De Walque (2006) does not indicate a correlation between education level and HIV status.

The implications of the epidemic, increased rates of severe illness and primeage adult mortality, suggest that the disease will have consequences for a host

All views are ours and do not reflect the views of the World Bank or its member countries. We thank John Strauss and the referees for their detailed comments, and Jere Behrman, T. Paul Schultz, and seminar participants at the IUSSP seminar on "HIV/AIDS and Poverty" and the 2006 annual meeting of the Population Association of America for very useful comments. For more information, contact Kathleen Beegle (kbeegle@worldbank.org).

(C) 2008 by The University of Chicago. All rights reserved. 0013-0079/2008/5602-0007\$10.00 
of socioeconomic indicators. This article adds to the literature by addressing an empirical issue that to date has been underexplored: the long-run implications on living standards of adult mortality shocks on surviving family members. The study focuses on the Kagera region in the North-West of Tanzania, an area that has been deeply affected by HIV/AIDS.

Research on the socioeconomic impact of AIDS is wide and varied. It can be partitioned into estimates of macroeconomic costs and analysis of household (microeconomic) impacts. Empirical analysis of the economic impact of high prime-age adult mortality due to HIV/AIDS and other fatal illnesses at the macroeconomic level draws mixed conclusions. Early examples of macroeconomic studies in this area include Over (1992), Cuddington (1993a, 1993b), Cuddington and Hancock (1994), Bloom and Mahal (1997), Arndt and Lewis (2000), and Quattek (2000). These macroeconomic studies have been critiqued for underestimating the impact of HIV/AIDS because they do not take into account the potential impact on human capital formation and its transmission between generations. On the one hand, Corrigan, Glomm, and Mendez (2005), Bell, Devarajan, and Gersbach (2006), and McDonald and Roberts (2006) extend these models in various ways to include the intergenerational effects on human capital accumulation and find large effects on national income per capita. On the other hand, Young (2005) models this orphan effect and finds that reduction in fertility dominates and results in higher per capita consumption possibilities.

The underpinnings of the macroeconomic studies are the behaviors and outcomes for individuals affected by HIV/AIDS—individuals who are infected and people with socioeconomic ties to the infected persons. There are several pathways through which an adult mortality can affect consumption or income levels among surviving household members. The direct costs of these events include medical expenses, as well as funeral costs (which can be larger than the medical costs in areas with low health care provision). Illnesses are associated with the loss of earnings for both the sick household members and caregivers in the household. Unearned income for households may also suffer if remittances are curtailed due to illnesses and mortality. Deaths can result in asset losses due to disinheritance (e.g., land grabbing). Finally, there may be significant intergenerational effects if illnesses and mortalities result in lower health and education investments in children (say, due to costs of illness and liquidity constraints), compromising the future income of these children when they reach adulthood. However, the per capita income standing of surviving households could theoretically rise through increases in labor scarcity that increase the value of time. This factor explains the results in the simulations by Young (2005), where the AIDS epidemic results in higher per capita consumption in the South African economy. 
While there is increasing evidence of short-run income impacts on households due to shocks such as large-scale fiscal crises (see works cited in Fallon and Lucas [2002]), morbidity shocks (Kochar 1995), and weather variation (Paxson 1992; Kinsey, Burger, and Gunning 1998), there are fewer studies on the income effects of deaths of household members. Grimm (2006) examines the consumption of survivors after the death of a household member in Indonesia, including deaths of children and elderly household members. In this setting, given low prevalence levels, deaths are unlikely to be due primarily to HIV/AIDS. Chapoto and Jayne (2008) and Christiaensen, Hoffmann, and Sarris (2007) study the relatively short-run impact of deaths on consumption levels (for deaths in the past 2 years in Zambia and Tanzania, respectively), while Yamano and Jayne (2004) study the impact of adult deaths on activities and particular sources of income. Consumption losses from health shocks can extend beyond the short-run impacts, as shown in the study of panel data from 1999 to 2004 from Ethiopia in Dercon, Hoddinott, and Woldehanna (2005).

In their recent review of household studies of the impact of HIV/AIDS morbidity and mortality on household income and expenditure, Naidu and Harris (2005) emphasize the gaps in this literature, including comprehensive measures of household expenditure (or income) and longitudinal data with which to track impacts over time. The lack of quantitative studies of the impact of an adult death at the household or individual level perhaps stems in large part from the difficulty in collecting data with the appropriate information to analyze the impact of adult mortality within households. To this end, this project follows on the panel data collected in the Kagera region of Tanzania (Kagera Health and Development Survey [KHDS]), a survey originally designed to assess the short-run impact of an adult death.

Studies of the baseline KHDS panel found that many households seem to recover from the shock in terms of consumption expenditure (see World Bank 1999, chap. 4). Lundberg, Over, and Mujinja (2000) study the various coping strategies that households employ, including private transfers, credit, and public assistance. As that study is based on an 18-month panel extending up to 2 years after the event, it is unclear if these outcomes reflect the long-term impacts. If households have short-run coping strategies (e.g., selling off assets, borrowing, or obtaining increased remittances from relatives) that are not sustainable in the long run, the true impact of these shocks may be quite different from the short-run outcomes. Long-run impacts could evolve if this shock results in changes in income or asset strategies, such as having a reluctance to engage in high-risk/high-return activities, holding more liquid and 
less productive assets, or making lower investments due to lower access to credit.

This article uses a 13-year panel of individuals to assess how adult mortality shocks affect both the short- and long-run consumption growth of surviving household members. For a sample of households who were first interviewed in 1991, in 2004 we traced these members, including those who had relocated or formed their own households. For each baseline household member who had died, a special mortality questionnaire was administered, recording the year the person had died and the reasons for the death, as well as identifying which of the surviving baseline household members he or she was living with at the time of the death. Our analysis will focus on the effect of the death of these baseline household members on the households they were living in at the time of death. We do this by regressing consumption growth between 1991 and 2004 on an indicator variable for whether any previous household member had died while residing in the household. The nature of our data allows us to control for baseline household fixed effects, offering identification of the effects of adult mortality via the different split-off households stemming from the same initial household. By thus exploiting the variation in outcomes across households whose members were all living together at baseline rather than at the time of the adult mortality event, we control more fully for heterogeneity in initial socioeconomic conditions that may be correlated with subsequent adult mortality and the path of consumption growth. We also control for the characteristics of the 2004 households, including household age fixed effects to account for the strong life cycle patterns one may expect to observe in consumption.

The following pattern emerges: an affected household will see consumption drop by $7 \%$ within the first 5 years after the adult death. Meanwhile, as this is a period of rather high consumption growth, the average household continues to grow at a rate that can be estimated to be about $13 \%$ over the same 5year period, creating a 19 percentage point growth gap. For deaths that occurred 6-13 years ago, we consistently find negative but insignificant effects. This may be suggestive of no persistence in the impact of adult death and a full recovery. However it may well be that other events blur the difference between affected and nonaffected households. A "casual observer," and even our relatively detailed data set, may then only imprecisely measure differences in consumption between affected and unaffected households, but a persistent effect, at least up to 13 years, seems plausible, if unproven, given our regression results. Further testing fails to find any evidence of risk sharing for adult mortality shocks among the 2004 households that originated from the sample of initial households. 


\section{Setting and Data}

The data for this study are from the Kagera region, an area far from the capital and coast, bordering Lake Victoria, Rwanda, Burundi, and Uganda. It is overwhelmingly rural and primarily engaged in producing bananas and coffee in the north and rain-fed annual crops (maize, sorghum, and cotton) in the south. Relatively low-quality coffee exports and agricultural produce are its main sources of income. It is not one the poorest areas of Tanzania; its mean per capita consumption was near the mean of mainland Tanzania in 2000. Growth and poverty reduction appears to mirror that in the rest of Tanzania: real GDP growth was just over $4 \%$ per year between 1994 and 2004, while poverty in Kagera is estimated to have changed very slightly, falling from $31 \%$ to $29 \%$ between 1991 and 2000-2001, according to the national data.

The Kagera region is nevertheless an area of early and high HIV prevalence. Kwesigabo et al. (2005) reported on three population samples in 1987 in districts of contrasting exposure in Kagera, finding, in 1987, overall ageadjusted HIV prevalence in urban Bukoba district of 24.2\%; of $10.0 \%$ in Muleba district, a medium-prevalence area; and of $4.5 \%$ in Karagwe district, a low-prevalence area. Subsequently, this baseline sample was followed further, and prevalence rates appear to have been coming down, due both to mortality and lower incidence. In urban Bukoba, prevalence went down to $18.2 \%$ in 1993 and $13.3 \%$ in 1996. In the other areas studied, prevalence also declined considerably, to $4.3 \%$ and $2.6 \%$ in Muleba and Karagwe, respectively, in 1999. Kwesigabo et al. (2005) note that the decline in these areas of different initial HIV-exposure suggests that the epidemic may have been arrested early without necessarily peaking to saturation levels. Nevertheless, and relevant for our study, a rapid decline in prevalence, even without any new incidence of HIV, was only possible due to large mortality in this period.

The Kagera Health and Development Survey (KHDS) was originally conducted by the World Bank and Muhimbili University College of Health Sciences (MUCHS). This survey covered 915 households that were interviewed up to four times from Autumn 1991 to January 1994 (at 6-7-month intervals). In addition to the household survey, the KHDS included surveys of communities, prices, and facilities. ${ }^{1}$ The KHDS 1991-94 serves as the baseline data for this article. The household questionnaire was a Living Standards Measurement Study survey instrument that contained numerous indicators of well-being, such as consumption, expenditure, asset holdings, morbidity,

\footnotetext{
${ }^{1}$ Information, documentation, and the full data set of the KHDS (1991-94 and 2004) can be found on the Living Standards Measurement Study Web site: http://www.worldbank.org/lsms/. For further description of the original project and the 1991-94 data, see Ainsworth et al. (1992) and World Bank (1993).
} 
health, nutrition, and education. Even though the sample was not specifically designed to be self-weighting, a comparison with the 1991 Household Budget Survey suggests that, in terms of basic welfare and other indicators, the baseline data are similar to a representative sample for this period from the Kagera region.

The KHDS 2004 was conducted in the first half of 2004 (Beegle, De Weerdt, and Dercon 2006a). The objective of the KHDS 2004 survey was to reinterview all individuals who were household members in any round of the KHDS 1991-94 and who were alive at the time of the last interview. This effectively meant turning the original household survey into an individual longitudinal survey. When a panel respondent was located, the household in which the individual lived in 2004 was administered the full household questionnaire. The KHDS 2004 used the original questionnaire as the foundation of the survey instrument to ensure comparability of all main indicators and variables from the earlier survey. For all panel respondents, there is a module on the incidence of economic shocks (both positive and negative) in the past 10 years.

Although the KHDS is a panel of respondents, the concept of a "household" after $10-13$ years is a vague notion. It is common in panel surveys to consider recontact rates in terms of households. Excluding households in which all previous members are deceased (17 households with 27 people), the field team managed to recontact $93 \%$ of the baseline households (i.e., at least one previous household member was reinterviewed in 2004). This is an excellent rate of recontact compared to panel surveys in low-income countries and high-income countries. The KHDS panel has an attrition rate that is much lower than that of other well-known panel surveys summarized in Alderman et al. (2001) in which the rates ranged from $17.5 \%$ attrition per year to the lowest rate of $1.5 \%$ per year. Most of these surveys in Alderman et al. (2001) covered considerably shorter time periods (2-5 years). From an individual respondent perspective, excluding people who died, $82 \%$ of all respondents (5,404 total) were located and reinterviewed.

Because many people moved out of the original household, the new sample in KHDS 2004 consists of about 2,700 households that were recontacted from the 832 baseline households. Much of the success in recontacting respondents was due to the effort to track people who had moved out of the 51 baseline communities (mostly villages). One-half of all households interviewed in 2004 were tracking cases, meaning that they did not reside in the baseline communities. Of those households tracked, only $38 \%$ were located near the baseline community. Overall, $32 \%$ of all households were not located in or relatively near the baseline communities. While tracking is costly, it is an important exercise because migration and dissolution of households are often hypothesized 
TABLE 1

SHOCKS EXPERIENCED, 1994-2003

\begin{tabular}{lcc}
\hline Type of Shock & Frequency & Percent \\
\hline Death of family member & 629 & 20 \\
Serious illness & 399 & 13 \\
Poor harvest due to adverse weather & 369 & 12 \\
Poor harvest due to pests or crop diseases & 75 & 2 \\
Poor crop prices & 71 & 2 \\
Problems with livestock & 3 & 0 \\
Loss of assets due to crime, violence, eviction, fire, etc. & 196 & 6 \\
Loss in wage employment & 127 & 4 \\
Loss in off-farm employment & 40 & 1 \\
Family problems & 49 & 2 \\
Lawsuits and imprisonment & 39 & 1 \\
Other reasons & 83 & 3 \\
\cline { 2 - 3 } Total & 2,080 & 67 \\
\hline
\end{tabular}

Note. The sample is 3,017 panel respondents who were 20 years and older in 2004 and who reported that any of the years 1994-2003 were "very bad."

to be important responses to hardship and strategies to escape poverty. Excluding these households in the sample raises obvious concerns regarding the selectivity of attrition. In particular, out-migration from the village, dissolving of households, and even marriage may be responses to changing economic or family circumstances. Thus, this relocation may be correlated with differential consumption growth paths. This is what is observed in these data: income outcomes for individuals who migrated are significantly different from those experienced by nonmigrants (see Beegle, De Weerdt, and Dercon 2006b). Moreover, respondents who moved farther away experienced the most income growth (where the greatest distance tends to be those who were residing in Dar es Salaam in 2004).

The main focus of this study is the impact of adult mortality on the subsequent consumption (or poverty) of survivors as much as 12 years later. Adult mortality is but one of many events that can have serious negative effects on future consumption outcomes. To get a sense of the overall scope of shocks as perceived by panel respondents, table 1 gives an overview of the most important shocks mentioned by the panel respondents of age 20 or older in 2004. Each panel respondent above the age of 20 reported, on a scale of 1-5, how their wealth and living conditions were in each year between 1994 and 2003. For each year labeled "very bad" (coded 5), the most important reason for this was asked. Table 1 shows that about two-thirds of the respondents reported at least one of these years as being very bad. About $20 \%$ of all respondents reported that their living conditions and wealth were "very bad" due to the death of a relative or other person; this is the most frequently mentioned reason. Serious illness and adverse weather conditions leading to 
harvest failure scored second and third place at $13 \%$ and $12 \%$ of panel respondents, respectively. In total, $16 \%$ of the panel respondents above 20 years of age reported at least 1 year to have been very bad because of agricultural problems (including negative effects of weather problems that affected prices of output and crop or livestock pests and diseases). Loss of assets due to crime, violence, eviction, fire, and so forth, as well as problems related to wages or other off-farm employment, were the next major category of shocks. About $2 \%$ of the respondents reported very bad living conditions because of family problems, $1 \%$ because of jail sentences or lawsuits.

One of the difficulties with measuring the events that have happened in order to assess the impact of the shock is that these events are usually selfreported by respondents. The problem, then, is that we may not have a measure of the event itself but rather a report of the event conditional on it being a significant negative economic shock from the perspective of the household. Thus, shocks reported by households will be endogenous, resulting in an upward bias in the impact of the event if more salient events are those whose socioeconomic impact is larger.

Using information on the survival status of our sample of baseline respondents, as well as information on the panel respondents with whom they resided when they died between the baseline and 2004 rounds, we will measure deaths not based on the panel respondent identification of the shock but rather from the actual event itself. ${ }^{2}$ However, for understanding how an adult death may be correlated with other negative events, we will also use the household reports of agricultural shocks, given the caveat above.

Table 2 shows the distribution of the occurrence of a death in the household (categorized by year and sex of the deceased) for the 2,611 households that had full information and that were used in the analysis. These are the households that were interviewed in 2004 that had at least one member who was included in the baseline data for the 1991-94 period. In total, 961 individuals we had interviewed in 1991 died before 2004. This study restricts the deaths considered to those of individuals who were aged 20-55 at the time of their death, who were included in the baseline data, and who were living with at least one other panel respondent at the time of their death. The data show that these deaths affected 644 panel households (in the sense that a member of the household suffered the loss of an adult living with them) on which we

\footnotetext{
${ }^{2}$ Household questionnaires that measure adult death through explicit questions on recent mortality episodes rather than a "shock" module in the household questionnaire will also avoid this issue. Other data that can also be used include information on events from a community questionnaire or rainfall data, both of which result in less variation as they measure covariate events.
} 
TABLE 2

PANEL HOUSEHOLDS EXPERIENCING THE DEATH OF A PRIME-AGE BASELINE RESPONDENT

\begin{tabular}{lcc}
\hline & \multicolumn{2}{c}{$\begin{array}{c}\text { Sample of Panel Households } \\
\text { Used in Main Regressions }\end{array}$} \\
\cline { 2 - 3 } Year of Death & Number & Percent \\
\hline $1991-95$ & 254 & 9.7 \\
Male death & 134 & 5.1 \\
Female death & 171 & 6.5 \\
1996-99 & 198 & 7.6 \\
Male death & 76 & 2.9 \\
Female death & 159 & 6.1 \\
$2000-2004$ & 192 & 7.4 \\
Male death & 76 & 2.9 \\
Female death & 149 & 5.7 \\
\hline
\end{tabular}

Note. $N=2,611$. The table presents the number of households out of the total number of households in the sample that had someone of the given gender die in the given time frame. For example, 254 out of 2,611 (9.7\%) of the sample's households experienced the death of a male in the time frame 1990-95.

have full baseline and follow-up data, constituting nearly one-quarter of the total sample of panel households.

\section{Methodology and Empirical Specification}

Using the sample of respondents interviewed in 2004, the objective of this study is to evaluate the impact of adult mortality on consumption for surviving respondents, focusing on the growth in consumption between the baseline and the follow-up survey. We use as the unit of observation the surviving panel household $i$, defined as a household that includes at least one survey respondent who was interviewed in the baseline. The treatment of interest is the adult mortality shock $D$. The relationship of interest used in the evaluation can be written as the following general specification:

$$
\left(\ln C_{i 1}-\ln C_{i 0}\right)=\beta X_{i 0}+\gamma D_{i}+\varepsilon_{i 1} .
$$

Consumption $(C)$ is measured in per capita terms at baseline (period 0 , which is the first KHDS 1991-94 interview; for most households this refers to an interview that took place in late 1991 or early 1992) and in 2004 (period 1). ${ }^{3}$ Since consumption growth may be characterized by substantial hetero-

${ }^{3}$ Consumption per capita is the annual per capita Tanzania shilling value of total household consumption, including actual consumer expenditures on food and nonfood items as well as the valuation of foods grown by farm households or received as gifts. The consumption values are in terms of average price level of the KDHS villages from January to June 2004. The average exchange rate during this period was 1,107 Tanzania shillings to 1 U.S. dollar. We compute baseline per capita consumption based on the first interview of the 1991-94 panel, as the questionnaire in this round is consistent with the 2004 questionnaire. For the second to fourth rounds of the 1991-94 data collection, the 
geneity among households, vector $X$ is a set of control variables, such as household characteristics of the respondents in the panel households, measured at baseline, including age, sex, wealth, education, and other initial conditions. Death $(D)$ captures the death of a previous household member living in household $i$ at the time of death. Thus, these deaths occur sometime between period 0 (October 1991 to January 1994) and period 1 (2004).

Estimated using ordinary least squares (OLS), equation (1) is equivalent to a difference-in-difference specification with a set of controls, and the parameter $\gamma$ offers the average treatment effect. There are important econometric difficulties with estimating equation (1). First, while the difference-in-difference specification controls for unobserved (time-invariant) heterogeneity affecting levels of consumption and $X_{i 0}$ captures observed heterogeneity affecting changes in consumption, there could be unobserved heterogeneity affecting consumption changes that are correlated with adult death. For example, deaths may occur with higher frequency in poor and vulnerable households with limited growth potential. The controls at baseline may not limit this problem sufficiently. Also, death could be endogenous to consumption, since consumption expenditures can influence health and mortality. ${ }^{4}$

Our (drastic) solution is to estimate a model with initial household fixed effects (IHHFE), whereby individuals are compared to others who were living with them in the same household in $1991 .^{5}$ Having data that follow individuals who have moved from the original household allows us to exploit the following variation: some baseline household members may be living with the deceased individual at the time of the death (between 1991 and 2004), while others will have moved into different households prior to the death (see app. A for further discussion). Defining the initial household for panel household $i$ as household $j$, we estimate

$$
\left(\ln C_{i 1}-\ln C_{i 0}\right)=\beta X_{i 0}+\gamma D_{i}+\nu_{j}+\varepsilon_{i 1},
$$

consumption modules are not identical. Specifically, the recall periods of several major subcomponents of the consumption aggregate refer to the 6-month intervals between survey rounds rather than to a 12-month recall.

${ }^{4}$ Grimm (2006), e.g., addresses this by instrumenting deaths. In our context, some of this concern is mitigated because the deaths are primarily caused by a disease that is almost always undiagnosed and fatal. Moreover, treatment is extremely limited; anti-retroviral (ARV) treatment has only recently been available for a small number of HIV-infected persons through the Kagera's regional hospital in Bukoba.

${ }^{5}$ Witoelar (2005) uses a similar approach that he calls extended family fixed effects. He studies consumption smoothing and income pooling among split-off households using data from the Indonesia Family Life Survey panel. He finds evidence against income pooling within the set of split-off households, although he does conclude that, to some degree, households within the extended family pool resources. 
where $\nu_{j}$ captures all (unobserved and observed) heterogeneity associated with belonging to initial household $j$ and $X_{i 0}$ is now restricted to the initial individual characteristics of panel individuals now residing in a particular panel household.

Nevertheless, more potential problems remain. First, adult mortality may be correlated with other shocks that occur. For example, the adult death may be correlated with agricultural shocks. We investigate this by including information on agricultural shocks for the sample of people aged 20 or older for whom we have this information. Second, the IHHFE framework implies that the impact of an adult death is identified based on a sample of households that may have split since the last 1991-94 survey interview and thus would have members who reside in different households by 2004. It is possible that the multiple households in 2004 that stem from the same origin household are rather different from each other; for example, some may consist of close relatives of each other while others may only consist of initial household members who are otherwise unrelated to other households in the dynasty, making the treatment group of household members (those who remained living with the person who will later die) incomparable to the comparison group of household members (those who will have split off before the person in question dies). To investigate this further, we rerun the regressions focusing on much narrower control and treatment groups, defined on the basis of a subsample of the data set in which we only consider initial households that include individuals with the same blood relationship to the adults who subsequently died. We report on three subsamples: children of the deceased; parents and children of the deceased; and spouses, parents, and children of the deceased. The variation used to identify the impact of the adult mortality shock is then based on those households splitting so that these different types of blood relatives are spread across different households. In all three subsamples, the control and treatment groups are then defined on the basis of a particular close blood relationship to the deceased.

Finally, the use of the IHHFE framework also creates a problem of interpretation. Since we only have one observation of changes in consumption, the use of the initial household fixed effect implies that we are jointly testing whether there is any impact of an adult mortality shock and whether there is risk sharing within all 2004 households from the same initial household. For example, it could be that a mortality death is very costly but that these costs are effectively insured by the other members of the same initial household so that the effect shows up as insignificantly different from zero on the mortality term since the entire effect is shared by the same "extended" family and is picked up by the initial household fixed effect. To disentangle these effects, 
we drop the initial household fixed effects and revert to a specification as in (1), include specific household baseline characteristics in $X_{i 0}$, and augment the regression with a term $D_{j}$ that captures the adult mortality shock of any initial panel respondent (which is the same for all split-offs from the same initial household). The regression then becomes

$$
\left(\ln C_{i 1}-\ln C_{i 0}\right)=\beta X_{i 0}+\gamma D_{i}+\varphi D_{j}+\nu_{j}+\varepsilon_{i 1} .
$$

If risk sharing of shocks were to take place, then the $\varphi$ should be significantly different from zero, controlling for a shock faced only by a particular panel household. Full risk sharing in the extended family would be implied if $\gamma=0$ as well.

\section{Regression Results}

We start by estimating equation (2) using IHHFE. Columns 1 and 2 of table 3 offer results excluding crop shocks; in columns 3 and 4, these shocks have been added. Since the shocks were only collected for panel respondents above 20 years of age, the sample is slightly smaller. We first offer a test of the impact of any adult mortality; whether we control for crop shocks or not, we find a strongly significant impact of a prime-age death on the household of the deceased. We find that the deaths that occurred between 2000 and 2004 reduce consumption growth by 30 percentage points $(30 \%$ of the standard deviation of the 13-year average of the regression sample). With average consumption growth in the sample used in column 3 at $45 \%$ over 13 years (about $3 \%$ per annum), this means that these households grew at a rate of $15 \%$ over the same 13-year period. ${ }^{6}$ Assuming that growth was equal across the years, a household experiencing an adult death between 2000 and 2004 would already have grown by $24 \%$ between 1991 and 1999; subsequently, it experiences a consumption downfall of 8 percentage points, or $7 \%$.

For the death occurring earlier than 2000-2004, the coefficients are negative, smaller in absolute value, and less significant. This pattern emerges in further specifications as well. Prime facie, this would be evidence that adult mortality shocks are not persistent at all: adult mortality shocks have no effects after 5 years, so there is a strong recovery. However, it would also be consistent with our inability to control fully for other shocks and events in this 13-year period: even if these shocks are not correlated with adult mortality shocks and therefore do not affect the point estimates in the regression, they do still create noise, confounding the difference between the treatment group and the control group.

${ }^{6}$ For a more detailed discussion of the factors driving consumption growth in this period in these data, see Beegle et al. (2006b). 
TABLE 3

CONSUMPTION GROWTH, 1991-2004: EFFECT OF A PRIME-AGED (20-55 YEARS) DEATH OF A BASELINE RESPONDENT ON SURVIVORS (INITIAL HOUSEHOLD FIXED EFFECTS)

\begin{tabular}{|c|c|c|c|c|}
\hline & (1) & (2) & (3) & (4) \\
\hline \multicolumn{5}{|l|}{ Death: } \\
\hline $1991-95$ & $\begin{array}{c}-.180 \\
(.156)\end{array}$ & & $\begin{array}{c}-.111 \\
(.171)\end{array}$ & \\
\hline 1996-99 & $\begin{array}{r}-.070 \\
(.145)\end{array}$ & & $\begin{array}{r}-.149 \\
(.157)\end{array}$ & \\
\hline $2000-2004$ & $\begin{array}{l}-.258 \\
(.117)^{\star \star}\end{array}$ & & $\begin{array}{l}-.298 \\
(.130)^{\star \star}\end{array}$ & \\
\hline \multicolumn{5}{|l|}{ Male death: } \\
\hline 1991-95 & & $\begin{array}{c}-.126 \\
(.223)\end{array}$ & & $\begin{array}{r}-.019 \\
(.245)\end{array}$ \\
\hline 1996-99 & & $\begin{array}{l}.055 \\
(.239)\end{array}$ & & $\begin{array}{c}.081 \\
(.269)\end{array}$ \\
\hline 2000-2004 & & $\begin{array}{c}-.172 \\
(.193)\end{array}$ & & $\begin{array}{c}-.057 \\
(.205)\end{array}$ \\
\hline \multicolumn{5}{|l|}{ Female death: } \\
\hline $1991-95$ & & $\begin{array}{l}-.388 \\
(.215)^{\star}\end{array}$ & & $\begin{array}{c}-.184 \\
(.236)\end{array}$ \\
\hline 1996-99 & & $\begin{array}{l}-.139 \\
(.173)\end{array}$ & & $\begin{array}{c}-.059 \\
(.182)\end{array}$ \\
\hline $2000-2004$ & & $\begin{array}{c}-.217 \\
(.140)\end{array}$ & & $\begin{array}{l}-.385 \\
(.156)^{\star \star}\end{array}$ \\
\hline \multicolumn{5}{|l|}{ Crop shock: } \\
\hline 1991-95 & & & $\begin{array}{l}-.398 \\
(.223)^{\star}\end{array}$ & $\begin{array}{l}-.400 \\
(.224)^{\star}\end{array}$ \\
\hline 1996-99 & & & $\begin{array}{l}-.191 \\
(.114)^{\star}\end{array}$ & $\begin{array}{c}-.184 \\
(.114)\end{array}$ \\
\hline 2000-2004 & & & $\begin{array}{l}-.168 \\
(.088)^{\star}\end{array}$ & $\begin{array}{l}-.174 \\
(.088)^{\star \star}\end{array}$ \\
\hline \multicolumn{5}{|l|}{ Additional controls: } \\
\hline \multicolumn{5}{|l|}{ Average number of biological } \\
\hline children living elsewhere & $\begin{array}{l}-.061 \\
(.026)^{\star \star}\end{array}$ & $\begin{array}{l}-.061 \\
(.026)^{\star \star}\end{array}$ & $\begin{array}{l}-.060 \\
(.026)^{\star \star}\end{array}$ & $\begin{array}{l}-.061 \\
(.026)^{\star \star}\end{array}$ \\
\hline Average years of schooling & $\begin{array}{c}.017 \\
(.011)\end{array}$ & $\begin{array}{l}.017 \\
(.011)\end{array}$ & $\begin{array}{l}.021 \\
(.011)^{\star}\end{array}$ & $\begin{array}{l}.021 \\
(.011)^{\star \star}\end{array}$ \\
\hline Share of males in initial household & $\begin{array}{l}.227 \\
(.049)^{\star \star \star}\end{array}$ & $\begin{array}{l}.227 \\
(.049)^{\star \star \star}\end{array}$ & $\begin{array}{l}.296 \\
(.052)^{\star \star \star}\end{array}$ & $\begin{array}{l}.299 \\
(.052)^{\star \star \star}\end{array}$ \\
\hline \multicolumn{5}{|l|}{ Share of chronically ill household } \\
\hline members & $\begin{array}{r}-.032 \\
(.093)\end{array}$ & $\begin{array}{c}-.037 \\
(.093)\end{array}$ & $\begin{array}{c}-.048 \\
(.095)\end{array}$ & $\begin{array}{r}-.048 \\
(.096)\end{array}$ \\
\hline Observations & 2,611 & 2,611 & 2,281 & 2,281 \\
\hline
\end{tabular}

Note. Unit of observation are households in 2004. Regressions include age fixed effects (i.e., a spline function allowing for different slope for each year). Regressions 3 and 4 have a smaller sample because the crop shock variable was only collected for panel respondents above 20 years old. Standard errors are in parentheses.

* Significant at the $10 \%$ level.

** Significant at the $5 \%$ level.

$\star \star \star$ Significant at the $1 \%$ level. 
In other words, we may be facing a problem of increasing imprecision in our ability to identify the impact of the shocks of a long time ago. While we may not be able to identify persistence, this is not strong evidence against persistence either.

Splitting the mortality variable up by the gender of the deceased and focusing on the specification controlling for crop shocks (table 3, col. 4) shows that this affect is driven by a large and relatively precisely estimated impact of female deaths from 2000 to 2004 and that no significant effect can be found for male deaths. The results in column 4 are consistent with those in columns 1 and 3 , and once we control for agricultural crop shocks, there are no significant persistent effects for mortality shocks that occurred more than 5 years ago. It is interesting to note that crop shocks display a more persistent negative effect than do mortality shocks: crop shocks going back to 1991 are significant and persistent for a long time, leading to growth losses with point estimates of between $17 \%$ and $40 \%$.

Initial household conditions may play an important role in the magnitude of the effect of deaths on income growth. We explore this potential heterogeneity by interacting adult death with baseline wealth of the household. Specifically, interaction terms are included for the mortality shock and whether the household belongs to the top quartile of household consumption in 1991 (rich) as well as whether the household had consumption below the median (poor). Table 4 shows some of the interactions that were investigated. In general, we do not find a significantly different impact according to wealth or poverty. Similarly, there was no evidence that crop shocks had different effects for rich or poor households. In all regressions explored, the adult death effect remains strongly significant and relatively stable.

The magnitude of the effect of adult deaths might also vary depending on the length of illness preceding the death, in addition to the realization of the death itself. Spells of illness prior to death are hypothesized to constitute periods of severe financial stress to households (for reasons noted above). The inclusion of a measure of length of illness (the number of months the person was ill before he or she died), however, did not have any additional explanatory power over the mortality variables (table 4 , col. 3 ). ${ }^{8}$

${ }^{7}$ For the period $1996-99$, the crop shock variable is only significant at $11 \%$ but has almost the same value and the same standard error as in the more parsimonious eq. (3). Testing a linear restriction on the three crop shocks suggests that they are not significantly different from each other $(F(2,1,416)=0.43)$ and that they are jointly significantly different from zero $(F(3,1,416)=4.11$ or significant at $1 \%)$. Crop shocks, even those that occurred more than 10 years ago, appear to have an impact.

${ }^{8}$ The information on months ill before death was collected using a specific instrument that probed for details on each mortality case. 
TABLE 4

CONSUMPTION GROWTH, 1991-2004: INTERACTION EFFECTS WITH PRIME-AGED (20-55 YEARS) DEATH OF A BASELINE RESPONDENT ON SURVIVORS (INITIAL HOUSEHOLD FIXED EFFECTS)

\begin{tabular}{|c|c|c|c|}
\hline & (1) & (2) & (3) \\
\hline \multicolumn{4}{|l|}{ Death: } \\
\hline $1991-95$ & $\begin{array}{r}-.058 \\
(.190)\end{array}$ & $\begin{array}{c}-.323 \\
(.290)\end{array}$ & $\begin{array}{c}-.145 \\
(.180)\end{array}$ \\
\hline 1996-99 & $\begin{array}{c}-.176 \\
(.180)\end{array}$ & $\begin{array}{c}.017 \\
(.226)\end{array}$ & $\begin{array}{c}-.211 \\
(.175)\end{array}$ \\
\hline 2000-2004 & $\begin{array}{l}-.347 \\
(.151)^{\star \star}\end{array}$ & $\begin{array}{l}-.438 \\
(.180)^{\star \star}\end{array}$ & $\begin{array}{l}-.318 \\
(.134)^{\star \star}\end{array}$ \\
\hline \multicolumn{4}{|c|}{ Baseline wealth interactions: } \\
\hline $1991-95$ & $\begin{array}{c}-.258 \\
(.436)\end{array}$ & & \\
\hline 1996-99 & $\begin{array}{l}.145 \\
(.370)\end{array}$ & & \\
\hline 2000-2004 & $\begin{array}{c}.214 \\
(.298)\end{array}$ & & \\
\hline \multicolumn{4}{|c|}{ Poor household and death: } \\
\hline $1991-95$ & & $\begin{array}{l}.337 \\
(.358)\end{array}$ & \\
\hline 1996-99 & & $\begin{array}{r}-.315 \\
(.313)\end{array}$ & \\
\hline 2000-2004 & & $\begin{array}{l}.269 \\
(.258)\end{array}$ & \\
\hline \multicolumn{4}{|c|}{ Length of illness (months ill before death): } \\
\hline 1991-95 & & & $\begin{array}{l}.009 \\
(.013)\end{array}$ \\
\hline 1996-99 & & & $\begin{array}{l}.005 \\
(.006)\end{array}$ \\
\hline 2000-2004 & & & $\begin{array}{l}.0002 \\
(.001)\end{array}$ \\
\hline \multicolumn{4}{|c|}{ Crop shock and interactions: } \\
\hline \multicolumn{4}{|l|}{ Crop shock: } \\
\hline $1991-96$ & $\begin{array}{c}-.331 \\
(.242)\end{array}$ & $\begin{array}{c}-.524 \\
(.364)\end{array}$ & $\begin{array}{l}-.398 \\
(.223)^{\star}\end{array}$ \\
\hline 1996-99 & $\begin{array}{l}-.231 \\
(.125)^{\star}\end{array}$ & $\begin{array}{l}-.286 \\
(.163)^{\star}\end{array}$ & $\begin{array}{l}-.189 \\
(.114)^{\star}\end{array}$ \\
\hline $2000-2004$ & $\begin{array}{c}-.160 \\
(.098)\end{array}$ & $\begin{array}{c}-.120 \\
(.133)\end{array}$ & $\begin{array}{l}-.169 \\
(.088)^{\star}\end{array}$ \\
\hline \multicolumn{4}{|c|}{ Rich household and crop shock: } \\
\hline $1991-96$ & $\begin{array}{c}-.431 \\
(.654)\end{array}$ & & \\
\hline 1996-99 & $\begin{array}{c}.244 \\
(.303)\end{array}$ & & \\
\hline 2000-2004 & $\begin{array}{r}-.050 \\
(.226)\end{array}$ & & \\
\hline \multicolumn{4}{|c|}{ Poor household and crop shock: } \\
\hline $1991-96$ & & $\begin{array}{l}.181 \\
(.466)\end{array}$ & \\
\hline 1996-99 & & $\begin{array}{l}.191 \\
(.231)\end{array}$ & \\
\hline $2000-2004$ & & $\begin{array}{r}-.077 \\
(.177)\end{array}$ & \\
\hline
\end{tabular}


TABLE 4 (Continued)

\begin{tabular}{lccc}
\hline & $(1)$ & $(2)$ & $(3)$ \\
\hline Additional controls: & & & \\
Average number of biological children of & & & \\
PHHM living elsewhere & -.061 & -.061 & -.060 \\
& $(.026)^{\star \star}$ & $(.026)^{\star \star}$ & $(.026)^{\star \star}$ \\
Average years of schooling & .020 & .021 & .021 \\
& $(.011)^{\star}$ & $(.011)^{\star}$ & $(.011)^{\star}$ \\
Share of males in initial household & .295 & .297 & .298 \\
& $(.052)^{\star \star \star}$ & $(.052)^{\star \star \star}$ & $(.052)^{\star \star \star}$ \\
Share of chronically ill household members & -.044 & -.048 & -.046 \\
& $(.096)$ & $(.096)$ & $(.096)$ \\
\hline
\end{tabular}

Note. $N=2,281$. "Poor" is defined as below median household consumption in 1991; "rich" is defined as top quartile household consumption in 1991. Length of illness is the number of months the deceased was ill before death. PHHM = previous household member. Regressions include age fixed effects (i.e., a spline function allowing for a different slope for each year). Standard errors are in parentheses.

* Significant at the $10 \%$ level.

** Significant at the $5 \%$ level.

$\star \star \star$ Significant at the $1 \%$ level.

As discussed in the previous section, the tests in tables 3 and 4 are a joint test of the impact of adult mortality shocks whether there is any impact of an adult mortality death and whether there is risk sharing within all splitoffs of the same initial household. As in equation (3), we overspecify the earlier regressions with a variable describing the mortality of any prime-age adult in the baseline survey belonging to the initial household. Under the null of full risk sharing, consumption changes should not be affected by mortality shocks of a baseline member residing with the particular household but should be significant for any mortality shock of a baseline member of the initial household. Table 5 presents the results.

To implement the test, the otherwise perfectly collinear initial household fixed effect will have to be dropped and be replaced by a vector also including a series of baseline household characteristics. We include initial asset values, household demographics (males/females aged 0-5, 6-15, 16-65, and 66+), characteristics of the head at baseline (number of years of education, sex, age, and age squared), and the number of children of the head living outside the household. The regression also includes a full set of cluster fixed effects, (mean) age fixed effects, the mean individual baseline characteristics of those residing together in 2004, and agricultural shocks. Finally, to capture initial household conditions more fully, we also include household consumption at baseline. Since this variable is most obviously likely to be endogenous (including but not exclusively due to measurement error, thereby affecting both the dependent variable and the initial level of consumption), it is necessary to explore the use of instrumental variables (IV) estimation. Finding credible instruments for initial consumption is not self- 
TABLE 5

CONSUMPTION GROWTH, 1991-2004: DISTINGUISHING BETWEEN INCOME POOLING AND SHOCKS

\begin{tabular}{|c|c|c|c|}
\hline & $\begin{array}{l}\text { Initial Household } \\
\text { Fixed Effect } \\
\text { (1) }\end{array}$ & $\begin{array}{l}\text { Non-IV } \\
\text { Cluster and Age } \\
\text { Fixed Effect } \\
\text { (2) }\end{array}$ & $\begin{array}{c}\text { IV Cluster } \\
\text { and } \\
\text { Age Fixed Effect } \\
\text { (3) }\end{array}$ \\
\hline \multicolumn{4}{|l|}{ Death: } \\
\hline 1991-95 & $\begin{array}{c}-.092 \\
(.177)\end{array}$ & $\begin{array}{l}-.018 \\
(.136)\end{array}$ & $\begin{array}{c}-.031 \\
(.138)\end{array}$ \\
\hline 1996-99 & $\begin{aligned}-.241 \\
(.166)\end{aligned}$ & $\begin{array}{l}-.087 \\
(.130)\end{array}$ & $\begin{array}{r}-.083 \\
(.131)\end{array}$ \\
\hline $2000-2004$ & $\begin{array}{l}-.324 \\
(.137)^{\star \star}\end{array}$ & $\begin{array}{l}-.210 \\
(.106)^{\star \star}\end{array}$ & $\begin{array}{l}-.210 \\
(.106)^{\star \star}\end{array}$ \\
\hline \multicolumn{4}{|l|}{ Any death from initial household: } \\
\hline 1991-95 & & $\begin{array}{l}-.019 \\
(.124)\end{array}$ & $\begin{array}{l}-.009 \\
(.125)\end{array}$ \\
\hline 1996-99 & & $\begin{array}{l}-.063 \\
(.113)\end{array}$ & $\begin{array}{l}-.067 \\
(.113)\end{array}$ \\
\hline 2000-2004 & & $\begin{array}{l}.112 \\
(.079)\end{array}$ & $\begin{array}{l}.121 \\
(.081)\end{array}$ \\
\hline \multicolumn{4}{|l|}{ Crop shock: } \\
\hline $1991-96$ & & $\begin{array}{l}-.137 \\
(.180)\end{array}$ & $\begin{array}{l}-.137 \\
(.180)\end{array}$ \\
\hline 1996-99 & & $\begin{array}{l}-.130 \\
(.095)\end{array}$ & $\begin{array}{l}-.130 \\
(.096)\end{array}$ \\
\hline 2000-2004 & & $\begin{array}{l}-.245 \\
(.071)^{\star \star \star}\end{array}$ & $\begin{array}{l}-.245 \\
(.071)^{\star \star \star}\end{array}$ \\
\hline \multicolumn{4}{|l|}{ Additional controls, 2004 household: } \\
\hline Average years of schooling of PHHM & $\begin{array}{l}.021 \\
(.011)^{\star}\end{array}$ & $\begin{array}{l}.026 \\
(.009)^{\star \star \star}\end{array}$ & $\begin{array}{l}.024 \\
(.009)^{\star \star \star}\end{array}$ \\
\hline Share of male PHHM & $\begin{array}{l}.304 \\
(.053)^{\star \star \star}\end{array}$ & $\begin{array}{l}.293 \\
(.048)^{\star \star \star}\end{array}$ & $\begin{array}{l}.292 \\
(.048)^{\star \star \star}\end{array}$ \\
\hline Share of chronically ill PHHM & $\begin{array}{c}-.074 \\
(.098)\end{array}$ & $\begin{array}{l}-.045 \\
(.076)\end{array}$ & $\begin{array}{l}-.042 \\
(.077)\end{array}$ \\
\hline $\begin{array}{l}\text { Average number of biological chil- } \\
\text { dren of PHHM living elsewhere }\end{array}$ & $\begin{array}{l}-.07 \\
(.027)^{\star \star}\end{array}$ & $\begin{array}{l}-.057 \\
(.021)^{\star \star \star}\end{array}$ & $\begin{array}{l}-.059 \\
(.021)^{\star \star \star}\end{array}$ \\
\hline \multicolumn{4}{|l|}{ Additional controls, baseline household: } \\
\hline Years of education head & & $\begin{array}{l}.006 \\
(.009)\end{array}$ & $\begin{array}{l}.003 \\
(.010)\end{array}$ \\
\hline Sex of head & & $\begin{array}{l}-.128 \\
(.061)^{\star \star}\end{array}$ & $\begin{array}{l}-.133 \\
(.062)^{\star \star}\end{array}$ \\
\hline Age of head & & $\begin{array}{c}-.011 \\
(.007)\end{array}$ & $\begin{array}{c}-.011 \\
(.007)\end{array}$ \\
\hline Squared age of head & & $\begin{array}{l}.0001 \\
(.00007)\end{array}$ & $\begin{array}{l}.0001 \\
(.00007)\end{array}$ \\
\hline \multicolumn{4}{|l|}{ Number of males ages: } \\
\hline $0-5$ years & & $\begin{array}{l}-.068 \\
(.026)^{\star \star}\end{array}$ & $\begin{array}{l}-.061 \\
(.029)^{\star \star}\end{array}$ \\
\hline $6-15$ years & & $\begin{array}{l}.075 \\
(.020)^{\star \star \star}\end{array}$ & $\begin{array}{l}.085 \\
(.026)^{\star \star \star}\end{array}$ \\
\hline $16-60$ years & & $\begin{array}{r}-.019 \\
(.022)\end{array}$ & $\begin{array}{c}-.014 \\
(.024)\end{array}$ \\
\hline $61+$ years & & $\begin{array}{r}-.013 \\
(.079)\end{array}$ & $\begin{array}{l}.012 \\
(.089)\end{array}$ \\
\hline
\end{tabular}


TABLE 5 (Continued)

\begin{tabular}{|c|c|c|c|}
\hline & $\begin{array}{l}\text { Initial Household } \\
\text { Fixed Effect } \\
\text { (1) }\end{array}$ & $\begin{array}{l}\text { Non-IV } \\
\text { Cluster and Age } \\
\text { Fixed Effect } \\
\text { (2) }\end{array}$ & $\begin{array}{c}\text { IV Cluster } \\
\text { and } \\
\text { Age Fixed Effect } \\
\text { (3) }\end{array}$ \\
\hline \multicolumn{4}{|l|}{ Number of females ages: } \\
\hline $0-5$ years & & $\begin{array}{l}-.053 \\
(.027)^{\star \star}\end{array}$ & $\begin{array}{l}-.048 \\
(.028)^{\star}\end{array}$ \\
\hline $6-15$ years & & $\begin{array}{c}.026 \\
(.018)\end{array}$ & $\begin{array}{c}.032 \\
(.021)\end{array}$ \\
\hline $16-60$ years & & $\begin{array}{l}.045 \\
(.020)^{\star \star}\end{array}$ & $\begin{array}{l}.050 \\
(.022)^{\star \star}\end{array}$ \\
\hline $61+$ years & & $\begin{array}{r}-.053 \\
(.050)\end{array}$ & $\begin{array}{r}-.045 \\
(.052)\end{array}$ \\
\hline Log of value of all assets & & $\begin{array}{l}.064 \\
(.026)^{\star \star}\end{array}$ & $\begin{array}{l}.050 \\
(.034)\end{array}$ \\
\hline $\begin{array}{l}\text { Log of consumption (instrumented in } \\
\text { col. 3) }\end{array}$ & & $\begin{array}{l}-.923 \\
(.046)^{\star \star \star}\end{array}$ & $\begin{array}{l}-.817 \\
(.182)^{\star \star \star}\end{array}$ \\
\hline
\end{tabular}

Note. $N=2,150$. Individual-level variables are means across all split-off panel respondents living together. PHHM = previous household member. Regressions include age fixed effects (i.e., a spline function allowing for a different slope for each year). Initial consumption is included as an endogenous variable instrumented by all right-hand-side variables interacted with $z$-scores of rainfall deviations in the year preceding the baseline, with positive rainfall deviations truncated to zero. Diagnostics for the IV regression are as follows: Cragg-Donald weak instrument F-statistic $=8.06$; Sargan statistic $14.66(p$-value $=$ .55). Regression 2 is the same as regression 1 without instrumented baseline consumption. Regression 3 is preferred FE regression model on IV model sample. Standard errors are in parentheses.

* Significant at the $10 \%$ level.

** Significant at the $5 \%$ level.

$\star \star \star$ Significant at the $1 \%$ level.

evident, but we have access to rainfall data preceding the baseline survey. In the Kagera farming system, droughts, and more generally poor rainfall, can present serious problems to crop income, so we use $z$-scores of rainfall deviations in the year preceding the baseline, with positive rainfall deviations truncated to zero. To allow for household-level variation, we use as identifying instruments all of the right-hand-side variables interacted with this truncated $z$-score. The full first-stage regression is reported in appendix B. The diagnostics for the instruments are encouraging: for example, the Cragg-Donald weak instrument $F$ statistic is 8.06 , while the Sargan overidentification statistic is 14.66 with a $p$ value of 0.55 .

Table 5 offers the results. First, column 1 offers the IHHFE findings for the particular (somewhat smaller) subsample for whom we have full information on all the controls used. As before, a clear negative effect of a prime age death can be found. Column 2 uses a specification as in equation (3), using all the controls, including initial consumption, but the latter is treated as exogenous. The impact of an adult mortality shock is again negative and significant at 5\%: perfect risk sharing is not taking place. The impact of any prime-age 
death of a respondent in the initial household, our means of assessing the presence of at least some risk sharing, is not significantly different from zero, implying that there is no evidence to suggest risk sharing between the splitoffs of the same initial household. However, this may a consequence of the presence of lagged consumption, a likely endogenous variable, as an explanatory variable. Column 3 therefore offers the same regression, this time using, as discussed above, the interaction of household characteristics with the truncated $z$-score of rainfall in the year preceding the baseline. The coefficient and standard error on deaths in the period 2000-2004 are virtually the same as without instrumenting, suggesting that the likely presence of endogeneity from including an initial value of consumption as a control variable did not affect our findings regarding the impact of a prime-age death in the household.

A final concern with the results presented in tables 3 and 4 using IHHFE is that the treatment and comparison groups may not be comparable: even though split-offs originate from the same initial household, there may be some nonrandom sorting into particular groups, making the evaluation of the impact of adult mortality flawed. For example, it may be that baseline individuals in a household were split into a group of relatives and nonrelatives of the deceased before the mortality shock. This could be either in anticipation of a period of hardship in the household or unrelated to it. For example, in anticipation of an adult dying, household splits may also involve the placement of the ill person with relatives only and not randomly across the split-offs. Our regressions already control for a range of variables, such as age fixed effects, sex, years of schooling, and the number of biological children of the respondent living outside the household at baseline. In order to specifically accommodate these concerns, we restricted our sample to create more directly comparable control and treatment groups. We report on three restricted subsamples: children of the deceased; parents and children of the deceased; and spouses, parents, and children of the deceased. The variation used to identify the impact of the adult mortality shock is then based on those households splitting so that these different types of blood relatives are spread across different households. While this may not solve all problems of (endogenous) placement across split-off households, it forces the comparison to be done between 2004 households with similar blood relatives. Table 6 reports the results, while table 7 shows the number of "useful" treatment observations from which the results are derived. In all specifications, the impact of adult death is strongly significant and larger in size as compared to the earlier results in table 3. It would appear that households of children living with a parent who dies are more strongly affected than other households and that the effect declines somewhat when broader categories of relatives are added. In view of the results, this would 


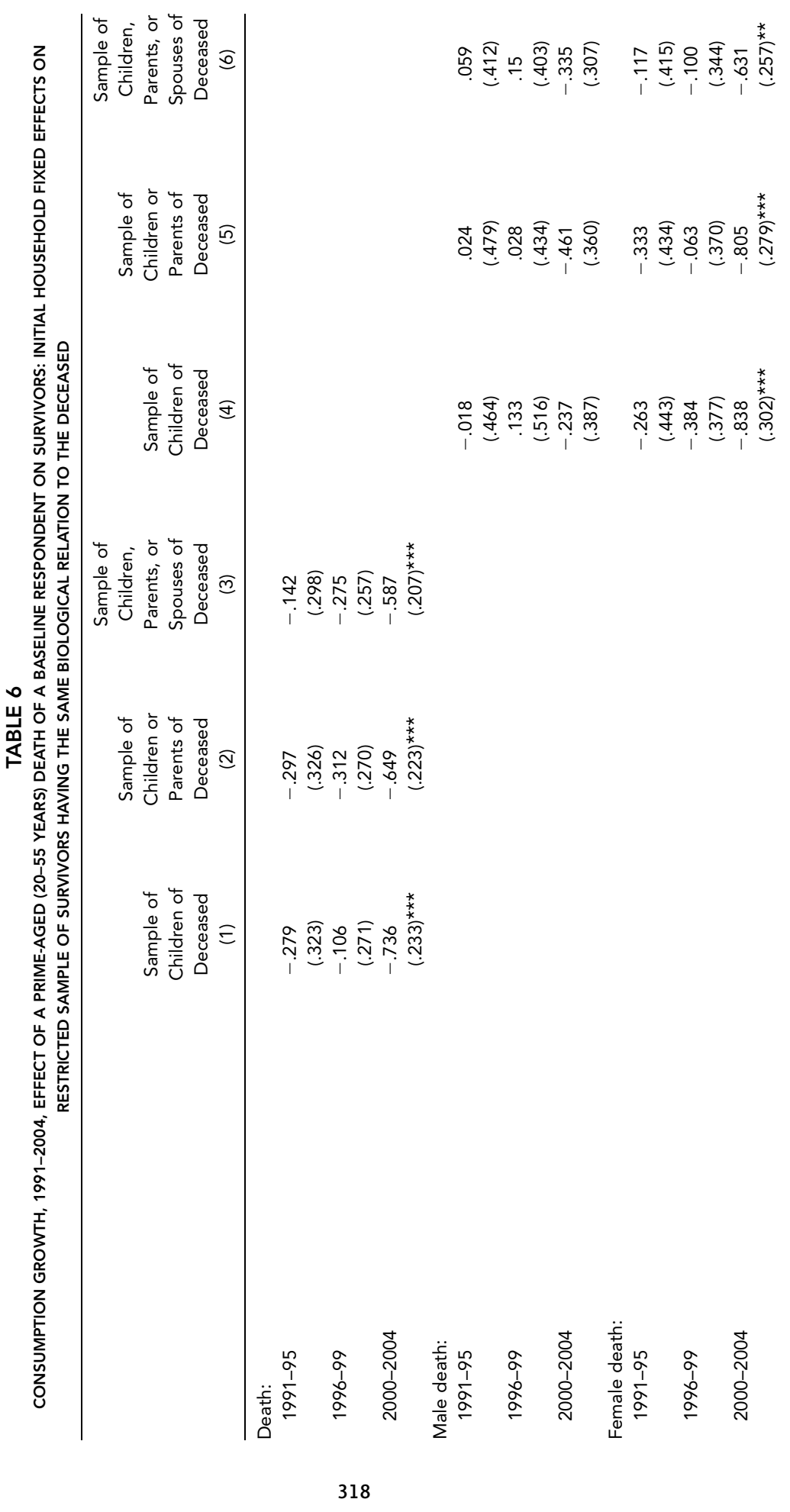




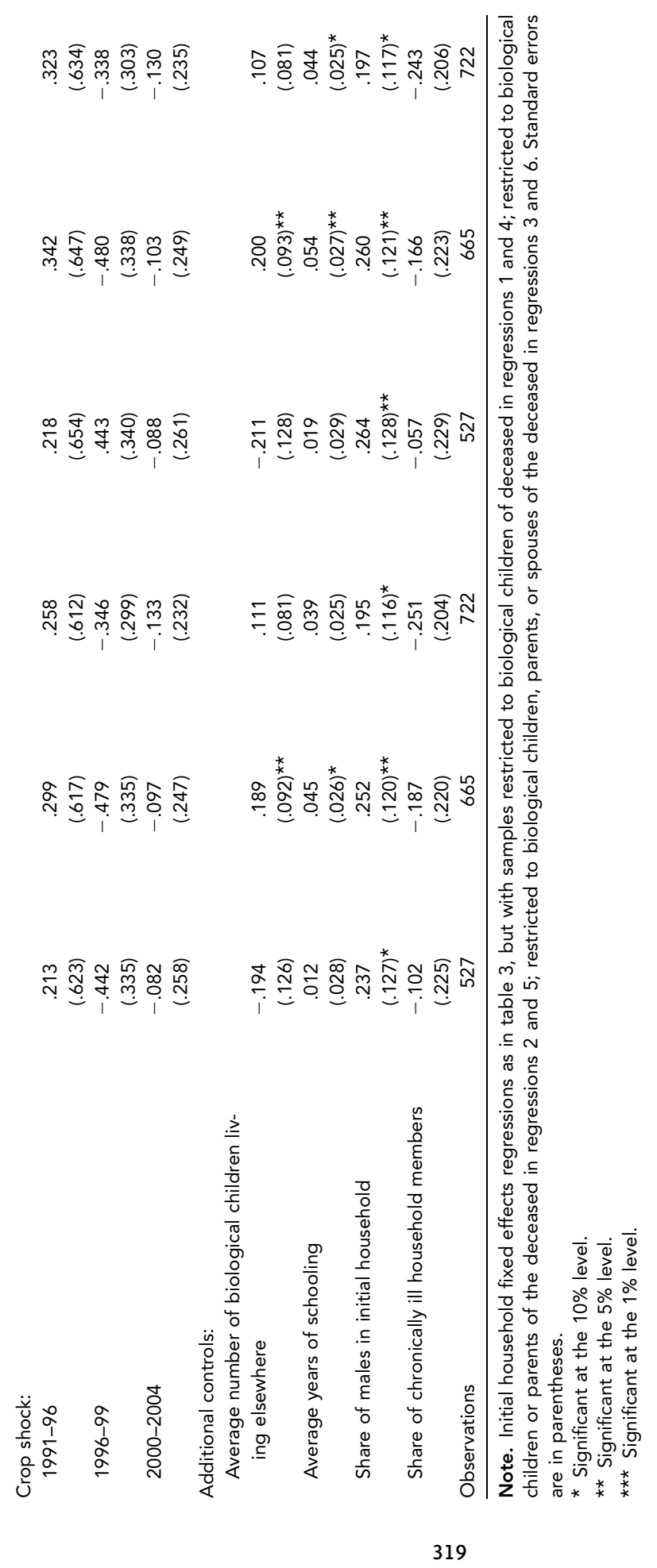


ECONOMIC DEVELOPMENT AND CULTURAL CHANGE

TABLE 7

NUMBER OF USEFUL TREATMENT OBSERVATIONS IN RESTRICTED SAMPLE OF TABLE 6

\begin{tabular}{|c|c|c|c|c|c|c|}
\hline & $\begin{array}{l}\text { Sample of } \\
\text { Children of } \\
\text { Deceased } \\
\text { (1) }\end{array}$ & $\begin{array}{l}\text { Sample of } \\
\text { Children or } \\
\text { Parents of } \\
\text { Deceased } \\
\text { (2) }\end{array}$ & $\begin{array}{l}\text { Sample of } \\
\text { Children, } \\
\text { Parents, or } \\
\text { Spouses of } \\
\text { Deceased } \\
\text { (3) }\end{array}$ & $\begin{array}{l}\text { Sample of } \\
\text { Children of } \\
\text { Deceased } \\
\text { (4) }\end{array}$ & $\begin{array}{c}\text { Sample of } \\
\text { Children or } \\
\text { Parents of } \\
\text { Deceased } \\
\text { (5) }\end{array}$ & $\begin{array}{c}\text { Sample of } \\
\text { Children, } \\
\text { Parents, or } \\
\text { Spouses of } \\
\text { Deceased } \\
\text { (6) }\end{array}$ \\
\hline \multicolumn{7}{|l|}{ Death: } \\
\hline 1991-95 & 35 & 51 & 56 & & & \\
\hline 1996-99 & 50 & 65 & 68 & & & \\
\hline 2000-2004 & 46 & 66 & 68 & & & \\
\hline \multicolumn{7}{|l|}{ Male death: } \\
\hline 1991-95 & & & & 20 & 31 & 34 \\
\hline 1996-99 & & & & 14 & 22 & 22 \\
\hline 2000-2004 & & & & 18 & 30 & 31 \\
\hline \multicolumn{7}{|l|}{ Female death: } \\
\hline 1991-95 & & & & 23 & 28 & 28 \\
\hline 1996-99 & & & & 32 & 41 & 45 \\
\hline 2000-2004 & & & & 33 & 43 & 46 \\
\hline
\end{tabular}

Note. The number of treatment observations in the sample from initial households with at least one nontreatment observation included in the sample.

also suggest that living in a household in which a nonrelative dies has less of an impact on consumption changes. Although not reported, this is confirmed in the data. Again, female deaths dominate the results, and male deaths do not appear to have a significant impact.

\section{Conclusions}

More than 20 years after the AIDS epidemic surfaced in Africa, it is perhaps surprising that there are significant gaps in empirical evidence of the impact of HIV/AIDS in regard to the income of surviving household members. This article uses unique longitudinal data designed to measure this impact. In the broader context, these results can be placed in the context of macroeconomic studies, which draw competing conclusions about the implications of the AIDS epidemic for national levels of income per capita. We provide evidence that adult mortality shocks, especially of females, have a large impact on the growth in consumption of surviving household members in a region of Tanzania that has been seriously afflicted by the HIV/AIDS epidemic.

In our sample, $22 \%$ of the households experienced an adult death between 1991 and 2004. We find significant and robust evidence that the impact of a prime-age death results in a $7 \%$ drop in consumption in the first 5 years after the death. After 5 years, the effect remains negative but becomes smaller and more imprecise. Statistically, the effects are not significant, so there is no evidence of a persistent impact of shocks after 5 years, suggesting a strong recovery. Nevertheless, we should be cautious with this interpretation. Is there really no 
persistence to these serious shocks? The regressions are not able to control for all other shocks and events, moving households up and down the consumption distribution, creating noise and potentially contributing to the imprecision of the estimates for mortality shocks that have occurred in the early part of the 13-year period. Given the point estimates, the lack of persistence is also not easily proven, although these point estimates are becoming smaller in absolute value for shocks that occurred a long time ago, so the effect may well be fading. This would suggest that a "casual observer" should not expect to see distinguishable differences between households who did or did not experience a primeaged adult death as long as 13 years ago but that the isolated effect of the death may well be persistent even to date and could have important economy-wide influence in high mortality areas. Of course, we are unable to confirm that this result reflects the actual time path of the impact of adult mortality on income or changes in regard to the income effects of adult mortality over this time period (1991-2004) as the scope of the epidemic changes in Tanzania.

The unique feature of our data set-that it follows individuals belonging to a baseline set of households reinterviewed more than 10 years later-allows us to show that these results are robust to household heterogeneity. The impact of death does not appear to be different between households that are richer or poorer at baseline. The effect on income growth appears largely linked to the mortality event; the impact does not vary with the length of the illness. We also did not find any evidence of risk sharing between different households split off from the original households at baseline, while the impact of adult death is higher when the death involves a close blood relative.

How households may have been able to cope in the long run is to be assessed further in these data. For example, it may be possible that such coping is achieved via further reorganization of the household, including via migration and household reformation. In Beegle and Krutikova (2006), it is found that orphans are more likely to marry young, while the migration of some individuals also can realign the returns to labor within the family. More research is needed to assess these issues more comprehensively. 


\section{Appendix A}

\section{Illustration of the Kagera Health and Development Survey Sample}

As described in the text, the set of baseline households in 1991 grew into more than 2,700 households in 2004. The flowchart (fig. A1) illustrates the potential configuration of a household in the KHDS sample and how it relates to our identification strategy using the initial household fixed effects (IHHFE) estimator. In the example in figure A1, in 1991 household X consists of four individuals A, B, C, and D. In 1998 household X has split into two households: household $\mathrm{X}^{\prime}$, consisting of individuals $\mathrm{A}$ and $\mathrm{B}$ and a new individual $\mathrm{E}$, and household X", consisting of individuals C and D. Between 1998 and 2004, person A dies, while household $\mathrm{X}^{\prime \prime}$ is joined by individual F. Using an IHHFE estimator, the effect of adult mortality will be identified from the comparison between household $\mathrm{X}^{\prime}$ and $\mathrm{X}^{\prime \prime}$, controlling for the otherwise shared history of both households $\mathrm{X}^{\prime}$ and $\mathrm{X}^{\prime \prime}$.

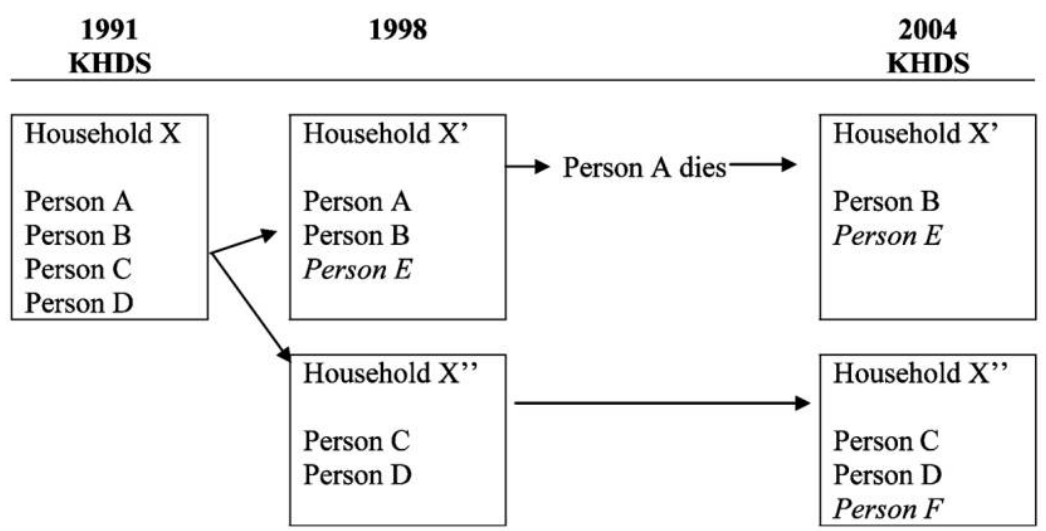

Figure A1. The Kagera Health and Development Survey sample

\section{Appendix B}

TABLE B1

FIRST-STAGE REGRESSION FROM TABLE 5 OF CONSUMPTION (LOG PER CAPITA), 1991

Coefficient Standard Error $t$-Value $P>|t|$

Included instruments:

Death:

1991-95

1996-99

2000-2004

Any death from initial household: 1991-95

$\begin{array}{rrrr}.106 & .064 & 1.640 & .10 \\ -.038 & .062 & -.610 & .54 \\ .011 & .050 & .220 & .82 \\ & & & \\ -.087 & .059 & -1.480 & .14\end{array}$


TABLE B1 (Continued)

\begin{tabular}{|c|c|c|c|c|}
\hline & Coefficient & Standard Error & t-Value & $P>|t|$ \\
\hline 1996-99 & .027 & .054 & .500 & .62 \\
\hline 2000-2004 & -.064 & .038 & -1.700 & .09 \\
\hline \multicolumn{5}{|l|}{ Crop shock: } \\
\hline $1991-96$ & -.018 & .085 & -.210 & .83 \\
\hline 1996-99 & .004 & .045 & .090 & .93 \\
\hline 2000-2004 & -.016 & .034 & -.470 & .64 \\
\hline \multicolumn{5}{|l|}{2004 household characteristics: } \\
\hline \multicolumn{5}{|l|}{ Average number of biological children of } \\
\hline PHHM living elsewhere & .003 & .015 & .190 & .85 \\
\hline Average years of schooling of $\mathrm{PHHM}$ & .014 & .007 & 1.880 & .06 \\
\hline Share of male PHHM & -.033 & .044 & -.760 & .44 \\
\hline Share of chronically ill PHHM & .012 & .069 & .170 & .86 \\
\hline \multicolumn{5}{|l|}{ Baseline household characteristics: } \\
\hline Years of education head & .044 & .008 & 5.420 & .00 \\
\hline Sex of head & .213 & .061 & 3.470 & .00 \\
\hline Age of head & -.021 & .007 & -2.910 & .00 \\
\hline Squared age of head & .000 & .000 & 3.870 & .00 \\
\hline \multicolumn{5}{|l|}{ Number of males ages: } \\
\hline $0-5$ years & -.118 & .025 & -4.700 & .00 \\
\hline $6-15$ years & -.059 & .018 & -3.310 & .00 \\
\hline $16-60$ years & -.057 & .020 & -2.890 & .00 \\
\hline $61+$ years & -.533 & .080 & -6.630 & .00 \\
\hline \multicolumn{5}{|l|}{ Number of females ages: } \\
\hline $0-5$ years & -.101 & .024 & -4.250 & .00 \\
\hline $6-15$ years & -.004 & .015 & -.260 & .80 \\
\hline $16-60$ years & -.053 & .018 & -3.040 & .00 \\
\hline $61+$ years & .021 & .048 & .430 & .66 \\
\hline Log of baseline value of all assets & .201 & .026 & 7.750 & .00 \\
\hline \multicolumn{5}{|l|}{ Excluded instruments: } \\
\hline $\begin{array}{l}\text { Interaction terms of negative rainfall devia } \\
\text { in } 1991 \text { (calculated as a truncated z- } \\
\text { score out of a } 25 \text {-year distribution) } \\
2004 \text { household characteristics: }\end{array}$ & & & & \\
\hline \multicolumn{5}{|l|}{ Average number of biological children of } \\
\hline PHHM living elsewhere & -.046 & .038 & -1.200 & .229 \\
\hline Average years of schooling of $\mathrm{PHHM}$ & -.001 & .020 & -.030 & .978 \\
\hline Share of male PHHM & -.072 & .121 & -.600 & .550 \\
\hline Share of chronically ill PHHM & .124 & .194 & .640 & .524 \\
\hline \multicolumn{5}{|l|}{ Baseline household characteristics: } \\
\hline Years of education head & .062 & .024 & 2.570 & .010 \\
\hline Sex of head & .484 & .171 & 2.820 & .005 \\
\hline Age of head & -.073 & .018 & -4.090 & .000 \\
\hline Age of head squared & .001 & .000 & 4.690 & .000 \\
\hline \multicolumn{5}{|l|}{ Number of males ages: } \\
\hline $0-5$ years & -.069 & .068 & -1.020 & .310 \\
\hline $6-15$ years & .133 & .051 & 2.590 & .010 \\
\hline $16-60$ years & -.004 & .053 & -.080 & .939 \\
\hline $61+$ years & -.905 & .208 & -4.360 & .000 \\
\hline \multicolumn{5}{|l|}{ Numbers of females ages: } \\
\hline $0-5$ years & -.144 & .070 & -2.060 & .039 \\
\hline $6-15$ years & .253 & .046 & 5.540 & .000 \\
\hline $16-60$ years & .001 & .048 & .030 & .980 \\
\hline $61+$ years & .261 & .123 & 2.120 & .034 \\
\hline Log of value of all assets & .219 & .074 & 2.970 & .003 \\
\hline
\end{tabular}

Note.-PHHM = previous household member. 


\section{References}

Ainsworth, Martha, Godlike Koda, George Lwihula, Phares Mujinja, Mead Over, and Innocent Semali. 1992. "Measuring the Impact of Fatal Adult Illness in SubSaharan Africa.” Living Standards Measurement Study no. 90, World Bank, Washington, DC.

Alderman, Harold, Jere R. Behrman, Hans-Peter Kohler, John Maluccio, and Susan Cotts Watkins. 2001. "Attrition in Longitudinal Household Survey Data: Some Tests for Three Developing-Country Samples.” Demographic Research 5 (November), article 4. http://www.demographic-research.org/volumes/vol4/4/.

Arndt, Channing, and Jeffrey D. Lewis. 2000. "The Macro Implications of HIV/AIDS in South Africa: A Preliminary Assessment." South African Journal of Economics 68, no. 5:1-32.

Beegle, Kathleen, Joachim De Weerdt, and Stefan Dercon. 2006a. "Kagera Health and Development Survey, 2004: Basic Information Document." World Bank, Washington, DC.

- 2006b. "Poverty and Wealth Dynamics in Tanzania: Evidence from a Tracking Survey." Photocopy, World Bank, Washington, DC.

Beegle, Kathleen, and Sofya Krutikova. 2006. "Impact of HIV/AIDS on Transition into Marriage.” World Bank Policy Research Working Paper no. 4139, World Bank, Washington, DC.

Bell, Clive, Shanta Devarajan, and Hans Gersbach. 2006. "The Long-Run Economic Costs of AIDS: With an Application to South Africa." World Bank Economic Review 20, no. 1:55-89.

Bloom, David, and Ajay Mahal. 1997. "Does the AIDS Epidemic Threaten Economic Growth?” Journal of Econometrics 77, no. 1:105-14.

Chapoto, Antony, and Thomas Jayne. 2008. "Impact of AIDS-Related Mortality on Rural Farm Households' Welfare in Zambia.” Economic Development and Cultural Change, in this issue.

Christiaensen, Luc, Vivian Hoffmann, and Alexander Sarris. 2007. "Gauging the Welfare Effects of Shocks in Rural Tanzania.” World Bank Policy Research Report, World Bank, Washington, DC. Forthcoming.

Corrigan, Paul, Gerhard Glomm, and Fabio Mendez. 2005. "AIDS Crisis and Growth.” Journal of Development Economics 77, no. 1:107-24.

Cuddington, John. 1993a. "Further Results on the Macroeconomics Effects of AIDS: The Dualistic Labor Surplus Economy.” World Bank Economic Review 7, no. 3:403-17. . 1993b. "Modelling the Macroeconomic Effects of AIDS, with an Application to Tanzania." World Bank Economic Review 7, no. 2:173-89.

Cuddington, John, and John Hancock. 1994. "Assessing the Impact of AIDS on the Growth Path of the Malawian Economy." Journal of Economic Development 43, no. 2:363-68.

Dercon, Stefan, John Hoddinott, and Tassew Woldehanna. 2005. "Shocks and Consumption in 15 Ethiopian Villages, 1999-2004." Journal of African Economies 14, no. 4:559-85.

De Walque, Damien. 2006. "Who Gets AIDS and How? The Determinants of HIV Infection and Sexual Behaviors in Burkina Faso, Cameroon, Ghana, Kenya and 
Tanzania.” World Bank Policy Research Working Paper no. 3844, World Bank, Washington, DC.

Fallon, Peter, and Robert E. B. Lucas. 2002. "The Impact of Financial Crises on Labor Markets, Household Incomes, and Poverty: A Review of Evidence.” World Bank Research Observer 17, no. 1:21-45.

Grimm, Michael. 2006. "Mortality and Survivors' Consumption.” Discussion Paper no. 611, DIW Berlin.

Kinsey, Bill H., Kees Burger, and Jan-Willem Gunning. 1998. "Coping with Drought in Zimbabwe: Survey Evidence on Responses of Rural Households to Risk." World Development 26, no. 1:89-110.

Kochar, Anjini. 1995. "Explaining Household Vulnerability to Idiosyncratic Income Shocks." American Economic Review Papers and Proceedings 85, no. 2:159-64.

Kwesigabo, Gideon, Japhet Killewo, Willy Urassa, Joe Lugalla, Maria Emmelin, Aldin Mutembei, Fred Mhalu, Gunnel Biberfeld, Stig Wall, and Anita Sandstrom. 2005. "HIV-1 Infection Prevalence and Incidence Trends in Areas of Contrasting Levels of Infection in the Kagera Region, Tanzania, 1987-2000." Journal of Acquired Immune Deficiency Syndrome 40, no. 5:585-91.

Lundberg, Mattias, Mead Over, and Phare Mujinja. 2000. "Sources of Financial Assistance for Households Suffering an Adult Death in Kagera, Tanzania.” World Bank Policy Research Working Paper no. 2508, World Bank, Washington, DC.

McDonald, Scott, and Jennifer Roberts. 2006. "AIDS and Economic Growth: A Human Capital Approach.” Journal of Development Economics 80, no. 1:228-50.

Naidu, Veni, and Geoff Harris. 2005. "The Impact of HIV/AIDS Morbidity and Mortality on Households: A Review of Household Studies." Special issue on HIV/ AIDs, South African Journal of Economics 73:533-44.

Ngom, Patrick, and Samuel Clark. 2003. "Adult Mortality in the Era of HIV/AIDS: Sub-Saharan Africa." Paper presented at Workshop on HIV/AIDS and Adult Mortality in Developing Countries, Population Division, Department of Economic and Social Affairs, United Nations Secretariat, New York.

Over, Mead. 1992. "The Macroeconomic Impact of AIDS in Sub-Saharan Africa." African Technical Department, Technical Working Paper no. 3, World Bank, Washington, DC.

Paxson, Christina. 1992. "Using Weather Variability to Estimate the Response of Savings to Transitory Income in Thailand." American Economic Review 82, no. 1: $15-33$.

Quattek, Kristina. 2000. "Economic Impact of AIDS in South Africa: A Dark Cloud on the Horizon." In HIV/AIDS: A Threat to the African Renaissance? ed. Robert Shell, Kristina Quattek, Martin Schönteich, and Greg Mills. Johannesburg: Konrad-Adenauer-Stifung.

Witoelar, Firman. 2005. "Inter-household Allocations within Extended Family: Evidence from the Indonesia Family Life Survey.” Discussion Paper no. 912, Economic Growth Center, Yale University.

World Bank. 1993. "Report of a Workshop on the Economic Impact of Fatal Illness in Sub-Saharan Africa." World Bank, Washington, DC and the University of Dar es Salaam. 
1999. Confronting AIDS: Public Priorities in a Global Epidemic. Rev. ed. New York: Oxford University Press.

Yamano, Takashi, and Thomas S. Jayne. 2004. "Measuring the Impacts of WorkingAge Adult Mortality on Small-Scale Farm Households in Kenya." World Development 32, no. 1:91-119.

Young, Alwyn. 2005. "The Gift of the Dying: The Tragedy of AIDS and the Welfare of Future African Generations." Quarterly Journal of Economics 120, no. 2:423-66. 
Copyright of Economic Development \& Cultural Change is the property of University of Chicago Press and its content may not be copied or emailed to multiple sites or posted to a listserv without the copyright holder's express written permission. However, users may print, download, or email articles for individual use. 